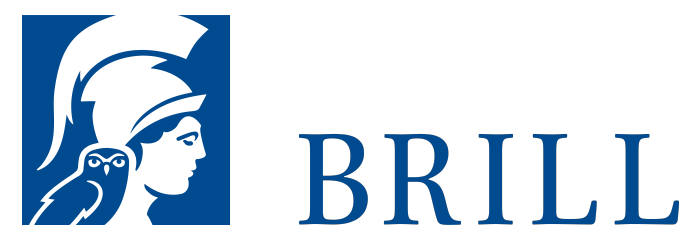

\title{
Der Platz zum Glauben
}

\section{Author: Peter Rohs}

Gegenstand des Buches sind die Bedingungen, denen theistische Überzeugungen genügen sollten, um unter den Vorgaben der Moderne als mit mündigem Denken vereinbar gelten zu können. Bedingungen ontologischer Art betreffen das Verhältnis von Gott zu Raum und Zeit. Gott sollte nicht als eine transzendente und unveränderliche Macht gedacht werden, sondern als freie Person, die tätig ist und darum auf Zukunft hin ausgerichtet. Andere Bedingungen ergeben sich aus dem Postulat der absoluten Heiligkeit Gottes. Sie schränken nicht nur ein, welche Antworten auf den Einwand der Theodizee denkbar sind, sondern legen auch nahe, dass das Zentrum eines theistischen Glaubens in der Hoffnung auf eine postmortale Fortexistenz moralischer Wesen und eine ideale Verwirklichung von Gerechtigkeit gesehen werden sollte.

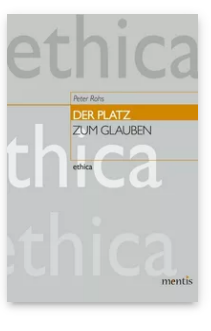

Pages: $15^{2}$

Seiten

Language:

German

Subjects:

General,

Philosophy

Publisher: Brill | mentis

Series:

ethica, Volume:

25

E-Book (PDF)

Released online:

04 Oct 2013

ISBN: $978-3-$

$89785-868-8$

List price

Paperback

Publication date:

o4 Oct 2013

ISBN: 978-3-

89785-323-2

List price 
For more information see brill.com

Order information: Order online at brill.com +44330 333 0049 | customerservices@brill.com Submission information: brill.com/authors

Titles published by Brill | Fink, Brill | mentis or Brill | Schöningh: +49(o)715413279216| brill@brocom.de 